\title{
Does 'clicking' matter? The role of online participation in adolescents' civic development
}

\author{
Hana Machackova \& Jan Šerek \\ Faculty of Social Studies, Masaryk University, Brno, Czech Republic
}

\begin{abstract}
This study focuses on the role of online civic participation in the civic development of adolescents. We build on the assumption that online civic participation differs from more traditional offline civic participation in several key characteristics, namely lacking proximity to other actors, possible disconnection between civic actions and their outcomes, and a reduced hierarchy within the online environment. Considering these specifics, the study examined the longitudinal effect of online participation on the development of civic identity, political self-efficacy, and attitudes toward social authorities. Concurrently, we contrasted the impact of online participation with the impact of offline civic participation. Data from a survey-based two-wave panel study conducted in Spring 2014 and Autumn 2015 in the Czech Republic were utilized. The sample comprised 768 adolescents (aged 14-17 in T1; $54 \%$ females). The results showed that online participation predicted increased challenging attitudes towards social authorities, while offline participation had the opposite effect. Furthermore, online participation had no effect on political self-efficacy or civic development, but offline participation positively predicted civic identity. The findings are discussed with regard to the specific benefits and limits of online civic participation.
\end{abstract}

Keywords: Online participation; adolescence; civic development

\section{Introduction}

Civic development is the process during which people become aware of public issues, develop their sociopolitical attitudes, and engage in various civic and political activities (e.g., Sherrod, Torney-Purta, \& Flanagan, 2010; Yates \& Youniss, 1998; Zaff, Malanchuk, \& Eccles, 2008). These activities are usually conceptualized as political and civic participation, though the specific conceptualizations differ across various studies. As noted in review conducted by Lutz, Hoffmann, and Meckel (2014), common definition of political participation is one articulated by Verba, Schlozman, and Brady $(1995$, p.7), denoting it as an "activity that is intended to or has the consequences of affecting, either directly or indirectly, government action". Civic participation is defined in a broader sense, such as "citizens' individual and collective involvement in public affairs" (Park \& Perry, 2008, p. 191). Although civic development can be understood as a never-ending, life-long process, numerous scholars pointed out the prominent role of adolescence in it (for a review, see Sears \& Brown, 2013). The main explanation is that adolescents, compared to older age groups, are characterized by a relative openness to socialization influences and subsequent attitude changes (Alwin \& Krosnick, 1991; Krosnick \& Alwin, 1989). In this context, there has been a growing emphasis on the fact that adolescents develop their sociopolitical attitudes not only through the transmission of attitudes from their families, schools, or media, but also through their own civic participation (Quintelier \& van Deth, 2014). Although adolescents are typically not eligible to vote, they can become engaged in public issues through other activities, such as taking part in political discussions, doing voluntary work for civil associations, signing petitions, or wearing clothing and accessories with social or political messages. It has been proposed that through these civic activities, young people might develop their civic 
identities (Yates \& Youniss, 1998), sense of agency (Beaumont, 2010; 2011), or other sociopolitical attitudes (Quintelier \& van Deth, 2014).

However, participatory activities differ in their impact on civic development. The recent debates often centered on the role of the internet activities and online participation. Online participation is analogous to offline participation, however, it is enhanced by conducting specific actions in the online environment, such as through social media (see Lutz et al., 2014). Additionally, as online and offline civic participation differ in several characteristics, such as the extent of interpersonal contact, it may lead to diverse civic outcomes in younger people. Previous research has highlighted both positive and negative potential of internet use and online participation in relation to young people's civic life (Bakker \& de Vreese, 2011; Buckingham, 2008; Dahlberg, 2007; Dahlgren, 2005, 2009; Chadwick \& Howard, 2010; Mossberger, Tolbert, \& McNeal, 2007; Smith, Schlozman, Verba, \& Brady, 2009). However, we are still lacking evidence on the impact of adolescents' online civic participation on the changes in their attitudes. In this study, we examine the longitudinal effects of youth civic participation on their civic identity, political self-efficacy, and attitudes toward social authorities. To understand the effects of online civic participation in a broader context, we contrast them with the effects of offline civic participation. Specifically, though both participatory types are often part of one complex participatory pattern, in our analysis we investigate their single effects independently one each other to gain a deeper understanding of their specificities.

\section{Online Civic Participation}

The rapid spread of the internet has created the possibility of participating in civic actions not only offline but also via online channels and platforms. This form of participation has quickly gained attention, especially in relation to youth (Bennett, 2008; Buckingham \& Willett, 2006; Livingstone, Couldry, \& Markham, 2007). Many online civic actions are, to some extent, analogous to offline ones, e.g. signing online petitions, discussing issues online, or expressing support for a political party on the website. Others can be more specific to the online environment, e.g. creating an interactive website centered on a certain political issue.

What is common to all online activities is that they are shaped by the specific affordances of the online environment. The use of the term affordance varies among scholars (see, e.g. Nagy \& Neff, 2015), however, crucial is the notion that diverse properties and qualities of the media and online environment can shape social behavior, including online participation. Some of the key characteristics of participation in the online environment are mentioned as beneficial and favorable: online activities are easily-accessed and low-cost, relatively open to content creation, enable encounters with diverse people, information, opinions and arguments, which can enhance awareness and interest (Dahlgren, 2009; Chadwick \& Howard, 2010). Moreover, the online environment has a potential for increased networking, information dissemination, and mobilization. It is favorable to less hierarchical and more democratic participation (e.g., in online discussions) and to the confrontation of diverse arguments (Dahlgren, 2009; Livingstone et al., 2007; Östman, 2012; Wojcieszak \& Mutz, 2009). Recent studies have focused on the potential of social media. For instance, boyd (2010) discusses new affordances of networked technologies, which affect social acts. These include persistence, replicability, scalability (i.e., potential visibility), and searchability of diverse content, such as information, materials, or expressions. As boyd states, these affordances introduce new dynamics which shape "networked publics": invisible audiences, collapsed contexts, and blurring of the private and the public. Considering these affordances, social media can impact numerous forms of online participation from opinion expressions, discussions, information sharing, and mobilizing for collective action (Kim, Hsu, \& de Zúñiga, 2013; Valenzuela, 2013; Warren, Sulaiman, \& Jaafar, 2014; Xenos, Vromen, \& Loader, 2014).

All these features of online civic participation can be advantageous compared to offline participation, especially for the youth (Livingstone, 2009). Majority of adolescents cannot engage in a prominent offline civic activity, voting, and their offline participation can be limited by the lack of resources and constraints of parents or school (Hirzalla \& van Zoonen, 2011). The online environment can represent an environment where the youth can engage more independently. Considering that large number of adolescents are equipped with sufficient digital skills for basic operations on the internet, (though differences still exist related to engagement and performance of diverse activities, including politics; Hargittai, 2010; Min, 2010) and are frequent users of digital technology and social media (Lenhart, 2015; Subrahmanyam \& Smahel, 2011; Tsitsika et al., 2014), the internet can provide 
an open and accessible ground for civic activities. For example, in the Czech Republic, from where this study originates, the internet is accessible to most young people. According to the Czech Statistical Bureau, in 2014 (the year of the first data collection), 93\% of households with children had internet access; moreover, 92\% of people aged 16-24 used social network sites in the previous three months (Český statistický úřad, n.d.). However, online political participation is, on average, less common (in 2014, 7\% of adults used internet for political activities such as online petitions, online communication with a politician, and online support to a political candidate, party, or event; Macková \& Macek, 2015). This is in line with the generally lower level of institutionalized and non-institutionalized political participation in Central and Eastern European countries as compared to Western European countries (Hooghe \& Quintelier, 2014).

Nevertheless, affordances of the online environment and consequently online form of participation received also consideration related to the possible drawbacks. A first possible drawback concerns the often-mentioned ease of performing online actions without constraints of spatial barriers. Besides its advantages, this characteristic of the online environment also means that online actions are usually conducted at a physical distance from others, without mutual visibility (Bargh \& McKenna; 2004). These features can diminish subjective connection to the targeted issues as well as the commitment put into the (less effortful) actions. The features of online participation can also affect perceptions of the effectiveness of the online actions. The external efficiency, i.e., the actual effect of online participation on targeted or pursued goals, has often been questioned. Though the empirical evidence is scarce (as pointed out by Vissers and Stolle, 2014), the doubts concerning the external efficiency of online participation have been reflected and studied under the concept of slacktivism or clicktivism, which denote the views on online participation as having no real-life impact besides an individual's selfsatisfaction (Christensen, 2011; Lutz et al., 2014; Morozov, 2011; Štětka \& Mazák, 2014). Furthermore, the potential for creating a more democratic environment unconstrained by authorities has also its downside in the form of increased un-civility, hostility, and the absence of actual debate. These outcomes might be more likely online than offline given the possibility of concealing one's identity and the lack of authority figures moderating ongoing debates (Edwards, 2002; Lampe, Zube, Lee, Park, \& Johnston, 2014; Suler, 2004; Wright \& Street, 2007). Moreover, the potential to encounter diverse individuals, opinions, and information is not necessarily realized. It is possible that despite the almost unlimited choice of diverse sources, individuals can select online groups and information that are simply confirming pre-existing perspectives, values, and opinions (Garrett, 2009; Kahne, Middaugh, Lee, \& Feezell, 2012; Wojcieszak \& Mutz, 2009). There is also a vast quantity of misleading or false information, including "fake news" or "clickbaits" (Chen, Conroy, \& Rubin, 2015; Tandoc et al., 2017), which creates biased impressions concerning civic and political issues. Additionally, the diverse and simply reachable online resources that are available include those that are directly anti-democratic, e.g. groups spreading extremist attitudes (Costello, Hawdon, Ratliff, \& Grantham, 2016; Pauwels \& Schils, 2016).

\section{The Effect of Online Participation on Civic Development}

Following this debate, prior research investigated differences and similarities between online and offline participation (Gibson \& Cantijoch, 2013; Hirzalla \& van Zoonen, 2011; Jugert, Eckstein, Noack, Kuhn, \& Benbow, 2013; Oser, Hooghe, \& Marien, 2013; Šerek \& Machackova, 2014; Vissers \& Stolle, 2014). Specific attention was paid to the question of how online participation affects youth civic development. This issue has been addressed by the examination of links between youth's political use of the internet and their civic or political participation. For example, Quintelier and Vissers (2008) showed in a sample of 16-year old respondents in Belgium that forwarding political e-mails was positively linked with offline political participation. A panel survey among Swedish adolescents showed that online political interaction increased both online and offline participation (Ekström \& Östman, 2013). In another panel study on a sample of US high school students, Kahne, Lee, and Feezell (2013) found that politically driven online participation was linked with greater political action and expression and campaign participation, but it was not related to civic participation or voting. Therefore, prior studies suggested the link between online activities and greater future participatory behavior. However, we still lack evidence about the specific effects of online participation on adolescents' civic attitudes. In the present study, we focused on the development of the following attitudes: civic identity, political self-efficacy, and attitudes towards social authorities. These attitudes reflect the motivation to engage in societal issues, shape orientation towards the society (and its leaders), and define the assessment of own capabilities in the pursuit of societal change. Thus, they are essential factors underlying civic behavior. Considering the specific factors of online participation, specifically the lack of proximity to other actors, disconnection between civic actions and 
the outcomes, and a reduced hierarchy within the online environment (Bargh \& McKenna, 2004; Suler, 2004; Valkenburg, Peter, \& Walther, 2016), we suggest that each of these attitudes can be impacted differently by the online and offline participation. In the text below, we introduce how these attitudes can be affected by participation in an online environment and specify our research questions regarding these attitudes.

Civic identity. First, by participating in collective civic actions, adolescents can develop psychological connections and a sense of responsibility to their fellow citizens, sometimes referred to as civic identity (Atkins \& Hart, 2003; Youniss, McLellan, \& Yates, 1997). Such development could be enhanced by the contact and a direct hands-on cooperation with people or groups coming from different backgrounds and facing diverse problems. However, online participation is mediated via online channels and is conducted at a relative distance from the people it concerns, including individuals as well as whole groups or communities. Hence, the contact often lacks direct interactions or non-verbal communicative cues (Bargh \& McKenna, 2004; Valkenburg et al., 2016). Consequently, the effect of online participation on the development of civic identity might be limited, particularly when compared with the effects of offline participation.

\section{RQ1: Does online participation predict changes in civic identity?}

Political self-efficacy. Another important component in civic development is the formation of internal political self-efficacy, i.e. a "personal belief regarding the ability to achieve desired results in the political domain through personal engagement and an efficient use of one's own capacities and resources" (Caprara, Vecchione, Capanna, \& Mebane, 2009; p. 1002). One of the most important ways through which self-efficacy is developed are mastery experiences, that is situations when individuals successfully achieve desired goals and attribute their success to their own abilities (Bandura, 1997; Beaumont, 2011; Pajares \& Urdan, 2006). Online participation might boost self-efficacy because it decreases participatory barriers and provides opportunities to take an active part in the civic processes even for those who would refrain from doing so offline (Kenski \& Stroud, 2006). However, selfefficacy is not dependent only upon engaging in the activities per se but depends also on subjective interpretations of one's accomplishments. Online participation may involve an absence of a connection to "visible" outcomes. Online actions are performed in a mediated environment, at a distance from the actors, raising the question of whether it can bring "tangible benefits" similar to offline interaction (Shah, Cho, Eveland, \& Kwak, 2005). Moreover, online environments offer not only a venue for participation but also multiple other activities (notably communication and entertainment), diverting users' attention from the pursued issues (Ekström, Olsson, \& Shehata, 2014). Considering also the expressed doubts about the lack of external efficiency of online participation, that is whether is online participation efficient in the achievement of stated goals, involvement in online participatory activities can result in lack of a sense of accomplishment due to the disconnection from visible or tangible outcomes. Thus, we can ask whether online participation substantially contributes to political self-efficacy development.

RQ2: Does online participation predict changes in political self-efficacy?

Attitudes toward social authorities. Finally, participation might be related to the development of adolescents' attitudes toward authorities or non-conventional behavior challenging prevailing rules and systems. These are reflected, for example, in the acceptance of non-conventional civic participation or, on the contrary, authoritarianism, i.e. beliefs in coercive social control, respect for authorities, and conformity to traditions (Duckitt, 2009). As described above, the online environment diminishes barriers (and inhibition of selfexpression) based on authority (Suler, 2004). In this sense, the internet potentially presents an environment enabling free speech of diverse actors, providing them with opportunities for challenging and contesting authorities (Akdeniz, 2002; Dahlgren, 2005; Dahlberg, 2007; Savigny, 2002). The internet also provides opportunities for increased awareness about the complexity of social issues by confrontation with diverse and non-conventional experiences and opinions (Brundidge, 2010). Therefore, we presume that online participation may increase people's acceptance of non-conventional behavior and make them less authoritarian, i.e. more vigilant toward social authorities.

RQ3: Does online participation predict changes in political self-efficacy? 
Differences from offline participation. Finally, all effects are considered not only with regard to selected attitudes, but also in comparison to the effects of offline participation. Though in many cases, civic participation is realized in both online and offline realm, questions prevail regarding the specific effects of online activities. Thus, our analysis will investigate the effect of both these participatory types independently, to assess whether their effects differ.

RQ4: Does online participation affect socio-political attitudes differently than offline participation?

\section{Aim of the Study}

This study's aim is to enhance our understanding of the role of online participation in adolescents' civic development. Specifically, we investigate how participatory activities affect the development of civic identity, political self-efficacy, and attitudes toward systems and authorities. To put the development of these characteristics in context, we concurrently examine the effect of participation in traditional, offline activities. In our investigation, we also control for possible effects of gender and school track, as these variables may diversify participatory patterns (Cicognani, Zani, Fournier, Gavray \& Born, 2012).

\section{Method}

\section{Participants and Procedure}

Data were taken from a broader longitudinal study conducted in the Czech Republic in mid-2014 (T1) and 1.5 year later (T2). This Central European country was a part the Eastern Block of communist countries until 1989 and today it is a member of the European Union (since 2004) with relatively advanced democracy (e.g., classified as a free country by the Freedom House or as a flawed democracy by the Economic Intelligence Unit; Economist Intelligence Unit, 2017; Freedom House, 2017). A random cluster sampling of schools was used within four (out of 14) Czech regions. The sample at T1 consisted of 1,137 high school students (53\% females) aged 14 to 17 at T1 $(M=15.99 ; S D=0.55)$, out of which 768 participated in both data collections and were included in the analyses (54\% females; $M=15.99 ; S D=0.55$ ). Two-thirds of the students $(67 \%$ in the original sample, $66 \%$ in the final sample) were from vocationally oriented high schools, while others were from academically oriented grammar schools.

Based on the preference of the school, paper (43\%) or online $(57 \%)$ questionnaires were administered at schools under the supervision of trained administrators. Students completed the questionnaire in one school hour (45 minutes) as a part of their classes and were not financially or materially rewarded for their participation. All foreign scales were translated into Czech using the translation back-translation procedure.

\section{Measures}

Online and offline civic participation (T1). Measures of participation were developed by the authors of the study. Respondents were asked whether they participated, in the past 12 months, in "activities linked to some social, local, environmental, or political issue". Six items captured online participation: signing an online petition (P1); expressing an opinion through a social network site (P2); trying to persuade somebody in an online discussion (P3); writing an online article or blog (P4); creating an SNS group or webpage (P5); voting in an online opinion poll (P6). Eight items measured offline participation: signing a printed petition (P7); taking part in demonstrations or protests (P8); helping an organization (P9); taking part in a cultural event (P10); distributing leaflets, posters or other materials (P11); wearing a T-shirt, badge or other symbol (P12); trying to persuade somebody in personal discussion (P13); leading a group of people (P14). The questions were responded to on an ordinal response scale consisting of "never" ( = 1), "once" ( = 2), "twice" ( = 3) and "more than twice" ( = 4). In total, $62 \%$ participants did at least one online activity and $79 \%$ at least one offline activity (see Table 1 for more details). For most activities, the frequencies of involvement did not significantly differ (Mann-Whitney $U$ test, ps>.05) between adolescents who were included in the longitudinal analyses $(n=768)$ and those who participated only at T1 $(n=369)$. The exceptions were wearing a T-shirt, badge or other symbol, which was more 
common for adolescents included in the analyses $(p<.05)$, and writing an online article or blog, which was more common for adolescents who were not included $(p<.05)$.

Table 1. Frequencies (\%) of Online and Offline Participatory Activities.

\begin{tabular}{lcccc}
\hline & Never & Once & Twice & More than twice \\
\hline Online participation & & & & \\
P1 Signing an online petition & 70 & 18 & 5 & 8 \\
P2 Expressing an opinion through a social network site & 63 & 18 & 6 & 14 \\
P3 Trying to persuade somebody in an online discussion & 84 & 8 & 3 & 5 \\
P4 Writing an online article or blog & 92 & 4 & 1 & 3 \\
P5 Creating an SNS group or webpage & 94 & 4 & 1 & 1 \\
P6 Voting in an online opinion poll & 62 & 20 & 6 & 12 \\
Offline participation & & & & \\
P7 Signing a printed petition & 69 & 22 & 6 & 3 \\
P8 Taking part in demonstrations or protests & 89 & 7 & 2 & 2 \\
P9 Helping an organization & 80 & 12 & 3 & 4 \\
P10 Taking part in a cultural event & 39 & 26 & 11 & 24 \\
P11 Distributing leaflets, posters or other materials & 78 & 12 & 4 & 6 \\
P12 Wearing a T-shirt, badge or other symbol & 72 & 16 & 4 & 8 \\
P13 Trying to persuade somebody in personal discussion & 74 & 15 & 4 & 8 \\
P14 Leading a group of people & 91 & 5 & 2 & 2 \\
\hline
\end{tabular}

Civic identity (T1 and T2). Three items were used to measure civic identity: "When you think about your life and your future, how important is it to you personally to (a) help the other ones, who had been less lucky (Cl1); (b) do something to improve community ( $\mathrm{Cl} 2)$; and (c) to help your own country (Cl3)?" (Flanagan, Bowes, Jonsson, Csapo, \& Sheblanova, 1998; Flanagan et al., 1999). A four-point response scale ranged from "not important at all" ( = 1) to "very important" ( = 4). $M_{\mathrm{T} 1}=3.00 ; M_{\mathrm{T} 2}=2.92$.

Political self-efficacy (T1 and T2). The scale was constructed based on general guidelines for creating selfefficacy scales (Bandura, 2006) and other political self-efficacy measures (Caprara et al., 2009; Sohl \& Arensmeier, 2015). Adolescents assessed whether they believed they could carry out four political activities in the place where they lived. Items were: "organize a demonstration (PE1)," "organize a petition (PE2)," "negotiate with local politicians (PE3)," "lead a group of people that is enforcing a certain cause (PE4)." Four-point response scales ranged from "absolutely disagree" ( = 1) to "absolutely agree" ( = 4). $M_{\mathrm{T} 1}=2.30 ; M_{\mathrm{T} 2}=2.29$.

Acceptance of non-conventional activism (T1 and T2). Adolescents' acceptance of non-conventional forms of political activism, our first indicator of attitudes towards social authorities, was measured by three items loosely based on measures of repressive potential (Finkel, Sigelman, \& Humphries, 1999; Marsh \& Kaase, 1979). Items were: "Protesters who disregard the police should always be punished hard (AN1)," "We should eliminate so called activists who only criticize the government but don't actually do anything (AN2)," and "Demonstrations and protests at squares should be under stricter control (AN3)." Four-point response scales ranged from "absolutely disagree" $(=1)$ to "absolutely agree" $(=4)$. All items were reversed so that a higher score indicates higher acceptance of non-conventional activism. $M_{\mathrm{T} 1}=2.47 ; M_{\mathrm{T} 2}=2.40$.

Authoritarianism (T1 and T2). The second indicator of attitudes towards social authorities, specifically adolescents' compliance with social authorities and traditions, was measured by six items selected from the scale of right-wing authoritarianism (Funke, 2005; translated to Czech by Tápal, 2012). Sample items: “Obedience and respect for authority are the most important values children should learn" or "The withdrawal from tradition will turn out to be a fatal fault one day." Four-point response scales ranged from "absolutely disagree" $(=1)$ to "absolutely agree" ( $=4$ ), a higher score indicates a higher authoritarianism. $M_{\mathrm{T} 1}=2.80 ; M_{\mathrm{T} 2}=2.87$.

\section{Data Analysis}

Four structural equation models predicting changes in civic identity, political self-efficacy, acceptance of nonconventional activism, and authoritarianism were estimated (using robust weighted least squares estimator) 
using Mplus 6.1 (see Figure 1). Ordinal indicators of online and offline participation were estimated using probit regressions. Other indicators were treated as continuous and estimated using linear regressions. Indicators of authoritarianism were reduced to three parcels using an item-to-construct balance procedure (Little, Cunningham, Shahar, \& Widaman, 2002). Occasional missing values were treated using a pairwise present approach.

\section{Results}

\section{Measurement Model of Civic Participation}

Confirmatory factor analysis showed that a two factor model assuming two correlated latent variables, representing online and offline activities $\left(\chi^{2} 74=216.14 ; C F I=.96 ; T L I=.96 ; R M S E A=.05 ;\right.$ WRMR $\left.=1.14\right)$, had a better fit than a one-factor model assuming that all activities indicated a single latent dimension $\left(\chi_{75}^{2}=501.54\right.$; $C F I=.89 ; T L I=.87 ; R M S E A=.09 ; W R M R=1.82)$. Standardized factor loadings in the two-factor model ranged from .43 to .91 (all factor loadings can be found in Figures 1 to 4 ) and the correlation between the factors was .63. No residual correlations had to be allowed except for correlations between signing online and offline petitions $(r=$ .38) and between trying to persuade somebody online and personally $(r=.56)$. Two indicators of convergent validity - average variance extracted (AVE) and composite reliability (CR) - showed a good validity (AVE>.50 and $C R>.70$ ) for online participation ( $A V E=.62, C R=.90$ ) and a slightly worse but acceptable validity for offline participation (AVE $=.43, \mathrm{CR}=.85)$.

\section{Measurement Invariance and Convergent Validity of Outcome Measures}

For each outcome variable, cross-time measurement invariance was tested by comparing a model assuming no invariance over time and a model assuming full metric and scalar invariance (i.e. identical unstandardized factor loadings and intercepts of indicators from T1 to T2). According to Cheung \& Rensvold (2002), a difference in CFI between the models should be lower than .01 to retain the assumption of invariance. Our analyses showed measurement invariance for all outcomes, that is for civic identity $(\triangle C F I=.003)$, political self-efficacy $(\triangle C F I=.005)$, acceptance of non-conventional activism $(\Delta C F /<.001)$, and authoritarianism $(\triangle C F I=.003)$. Thus, all subsequent models were restricted to assume full metric and scalar measurement invariance of outcome variables.

To further investigate convergent validity of our outcome measures, we computed AVE and CR scores for all outcomes $T 1$ and $T 2$. These indices showed a good validity $(A V E>.50$ and $C R>.70)$ for civic identity $\left(A V E_{T 1}=.57\right.$, $\left.\mathrm{CR}_{\mathrm{T} 1}=.80, \mathrm{AVE}_{\mathrm{T} 2}=.55, \mathrm{CR}_{\mathrm{T} 2}=.79\right)$, political self-efficacy $\left(\mathrm{AVE}_{\mathrm{T} 1}=.67, \mathrm{CR}_{\mathrm{T} 1}=.89, \mathrm{AVE}_{\mathrm{T} 2}=.68, \mathrm{CR}_{\mathrm{T} 2}=.89\right)$ and authoritarianism ( $\left.\mathrm{AVE}_{\mathrm{T} 1}=.65, \mathrm{CR}_{\mathrm{T} 1}=.85, \mathrm{AVE}_{\mathrm{T} 2}=.69, \mathrm{CR}_{\mathrm{T} 2}=.87\right)$, and a slightly worse validity for acceptance of non-conventional activism $\left(\mathrm{AVE}_{\mathrm{T} 1}=.46, \mathrm{CR}_{\mathrm{T} 1}=.71, \mathrm{AVE}_{\mathrm{T} 2}=.39, \mathrm{CR}_{\mathrm{T} 2}=.65\right)$.

\section{Longitudinal Effects of Online and Offline Participation}

Results from the main analyses are presented in Figures 1 to 4 . Changes in civic identity were positively predicted by offline but not online participation (which had a weak negative but non-significant effect). On the other hand, changes in the acceptance of non-conventional activism were positively predicted by online but not offline participation. Standardized effects of participation on changes in authoritarianism were greater than .10, online participation predicting authoritarianism negatively while offline participation predicting authoritarianism positively, but they were significant only at the .06 level. Finally, changes in political self-efficacy were not predicted by online or offline participation. 


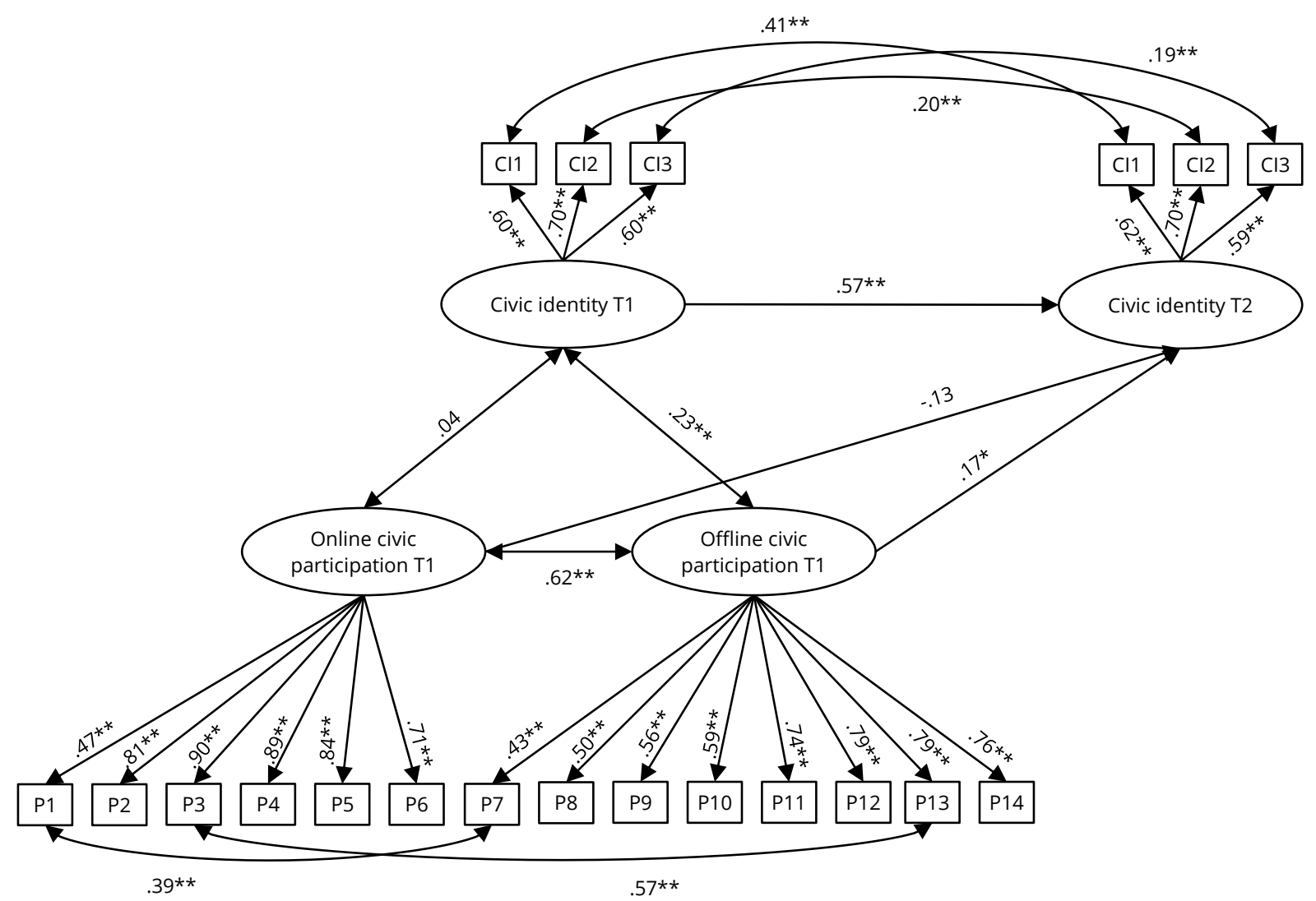

Figure 1. Structural model predicting changes in civic identity. Model fit: $\chi_{201}^{2}=501.01, C F I=.93$, $T L I=.92, R M S E A=.04, W R M R=1.33$. Effects of academic school track $(\beta=-.01 ; p>.05)$ and female gender $(\beta=.22 ; p<.01)$ on civic identity at T2 were controlled. Standardized coefficients are presented. ${ }^{*} p<.05 . * * p<.01$.

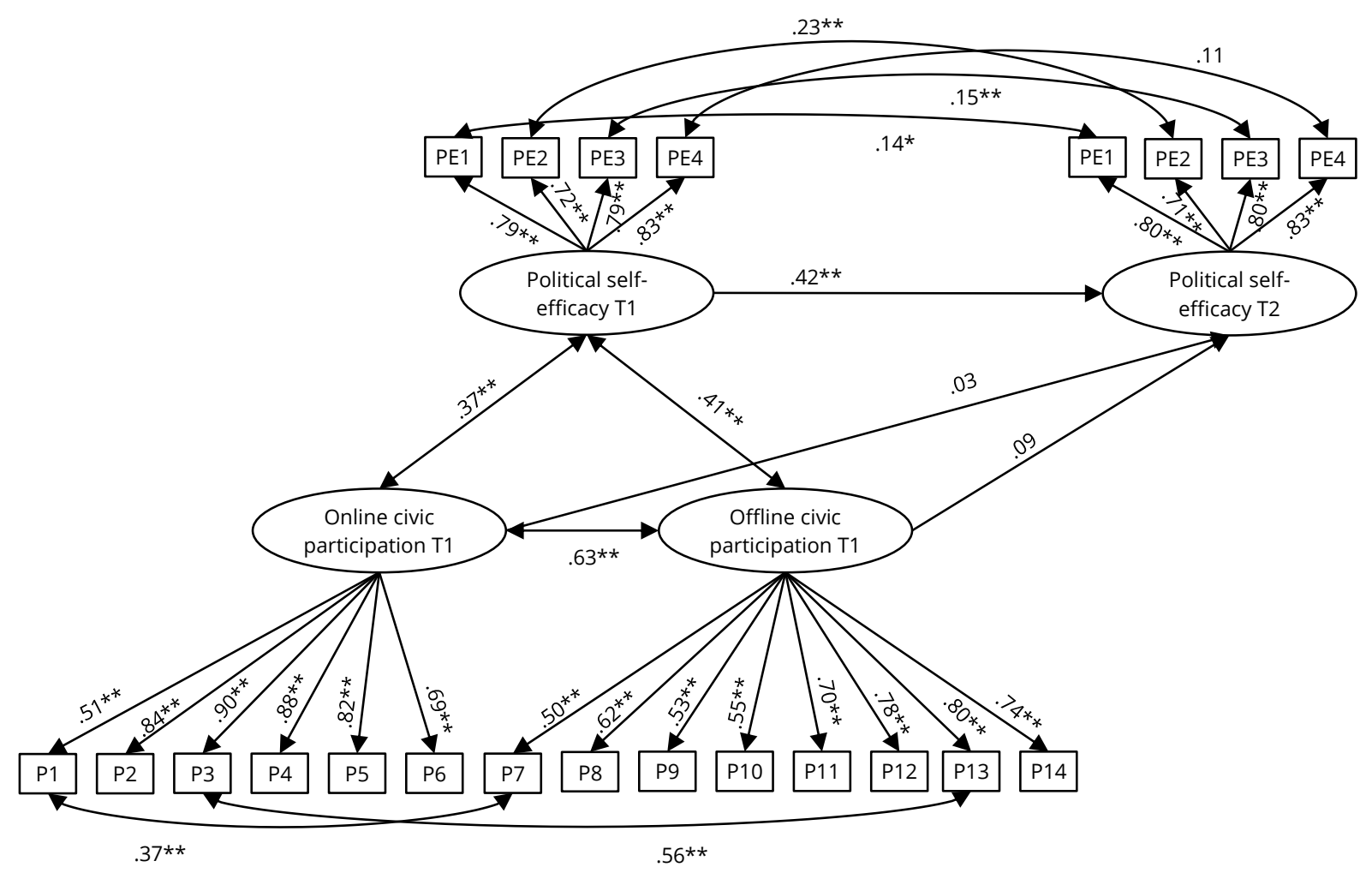

Figure 2. Structural model predicting changes in political self-efficacy. Model fit: $\chi^{2}{ }_{245}=562.57$, $\mathrm{CFI}=.93, \mathrm{TLI}=.93, \mathrm{RMSEA}=.04, \mathrm{WRMR}=1.25$. Effects of academic school track $(\beta=.05 ; p>.05)$ and female gender ( $\beta=-.01 ; p>05$ ) on political self-efficacy at T2 were controlled. Standardized coefficients are presented. ${ }^{*} p<.05 .{ }^{* *} p<.01$. 


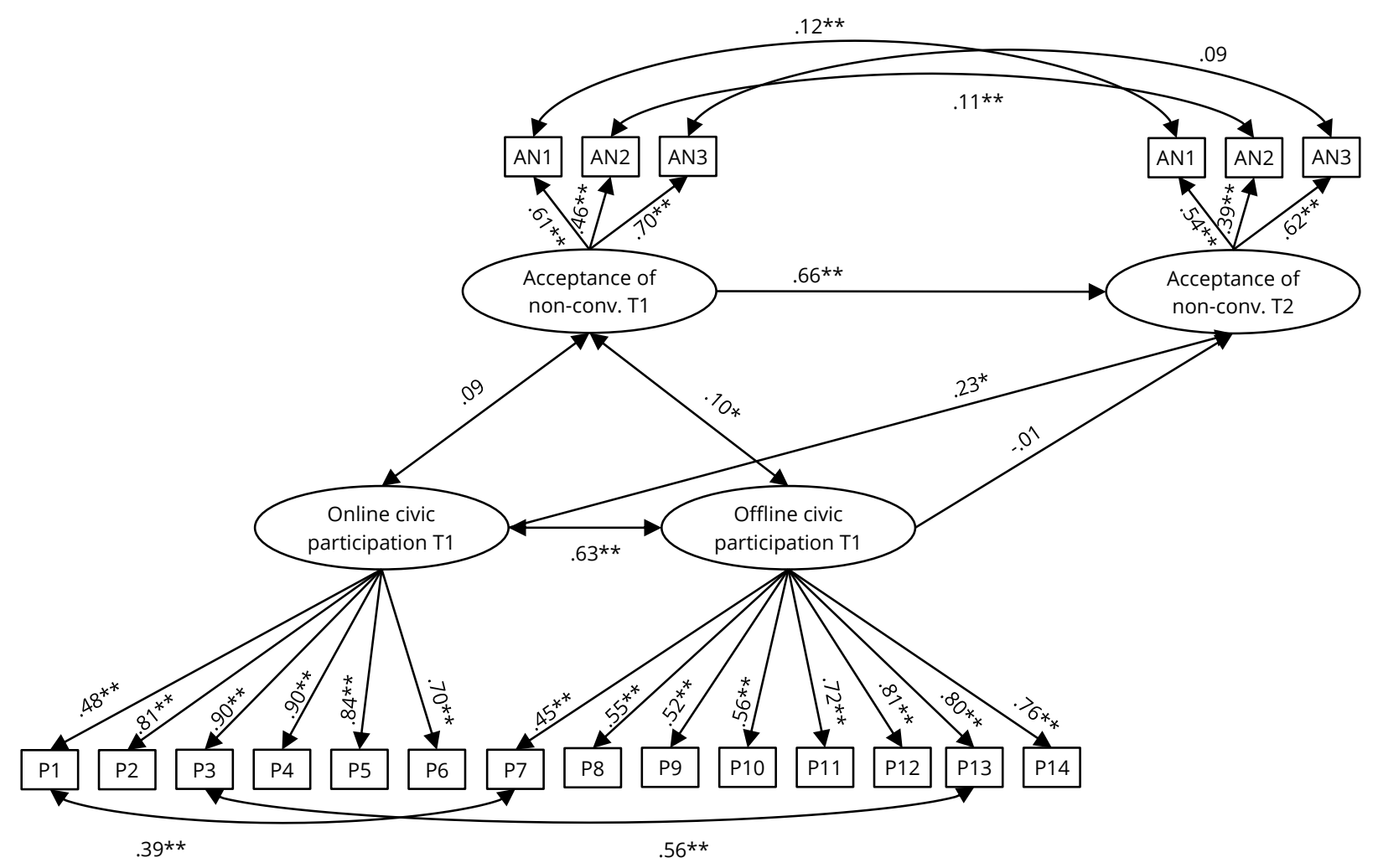

Figure 3. Structural model predicting changes in acceptance of non-conventional activism. Model fit: $\chi_{201}^{2}=428.93, C F I=.95, T L I=.94, R M S E A=.04, W R M R=1.21$. Effects of academic school track $(\beta=-.07 ; p>.05)$ and female gender $(\beta=-.03 ; p>.05)$ on acceptance at T2 were controlled. Standardized coefficients are presented. ${ }^{*} p<.05 .{ }^{*} p<.01$.

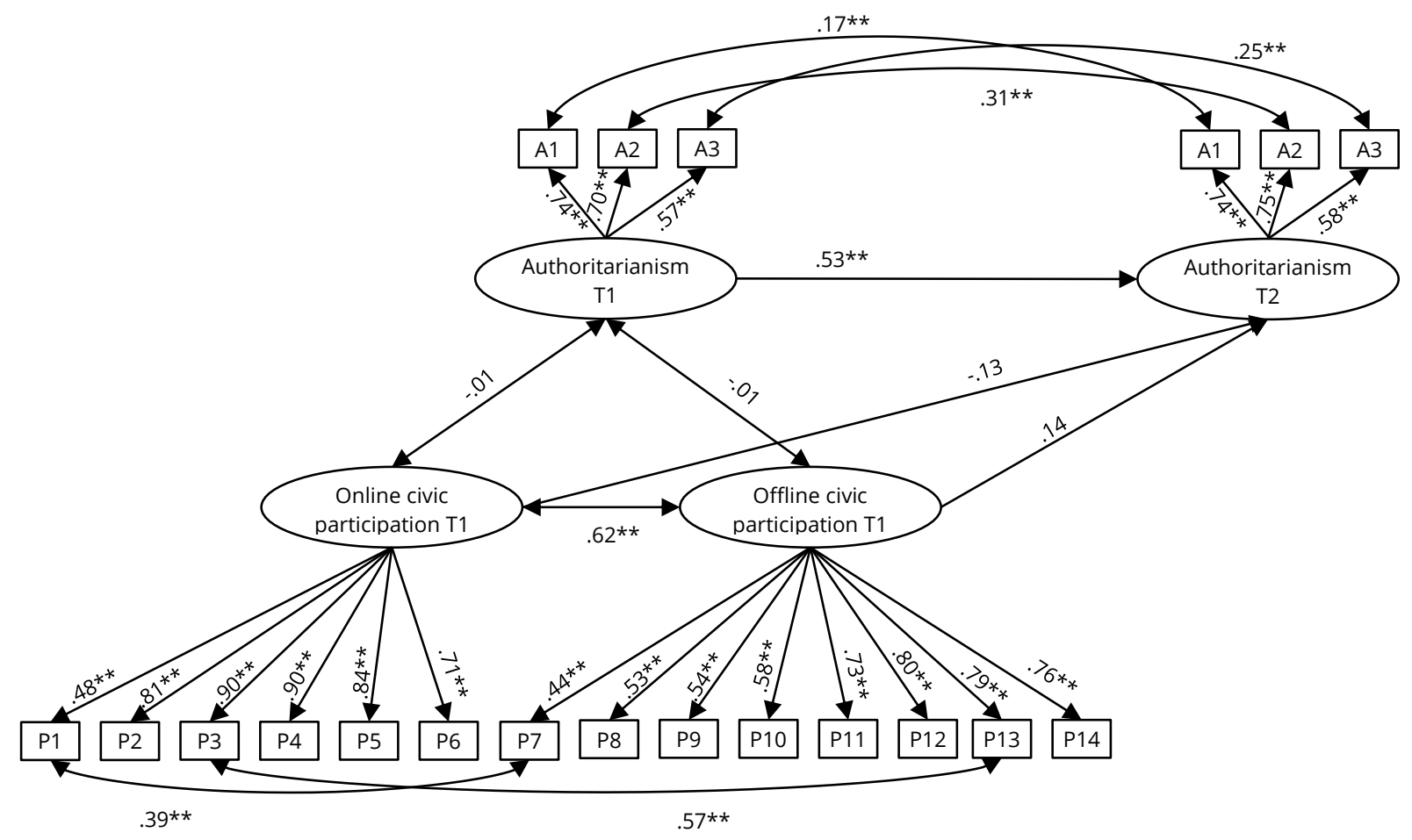

Figure 4. Structural model predicting changes in authoritarianism. Model fit: $\chi^{2}{ }_{201}=413.15$, $C F I=.95, T L I=.95, R M S E A=.04, W R M R=1.18$. Effects of academic school track $(\beta=-.12 ; p<.01)$ and female gender $(\beta=-.02 ; p>.05)$ on authoritarianism at T2 were controlled. Standardized coefficients are presented. ${ }^{*} p<.05 .{ }^{*} * p<.01$. 


\section{Discussion}

Our study investigated the role of online civic participation in adolescents' civic development, specifically in the development of civic identity, political self-efficacy, and attitudes toward social authorities. Results revealed that online and offline civic participation affected the formation of adolescents' attitudes differently.

The findings showed that the development of civic identity (the sense of connection and responsibility to fellow citizens) was not affected by online participation, but it was positively predicted by offline participation. The lack of an effect of online participation could be explained by its specific character: online participation is typically performed at a relative distance from other people, demanding no direct interactions or hands-on cooperation. As suggested by Metz, McLellan, and Youniss (2003), youth concern for the broader society and fellow citizens is often raised through direct participation in activities within a communal or organizational context that explicitly expresses pro-societal stances and norms. Such direct exposure typically accompanies many offline activities, such as volunteering for civic organizations or organizing public protests. On the other hand, these experiences might be limited or even lacking in online participation that involves virtual forms of interpersonal contact.

Next, our findings suggested no effect of online or offline participation on adolescent's political self-efficacy. This finding might be considered surprising because adolescents' practicing of their civic skills via both types of participation should help them to gain mastery experiences that, consequently, would increase their confidence in their own capabilities (Beaumont, 2010). Consistent with our expectations, one explanation for our findings regarding online participation could be that online activities provide only a limited number of opportunities to feel a sense of accomplishment, which is one of the important factors in the development of self-efficacy (Bandura, 1997). However, considering that offline activities also did not have any effect on participants' political self-efficacy, alternative explanations seem to be more plausible. One of them is that the one and half year time lag between our first and second measurement was too short to provide adolescents with enough mastery experiences that would affect their sense of efficacy. Another explanation concerns our measurement of political self-efficacy, which was relatively narrowly focused only on some types of civic activities, such as organizing a demonstration or negotiating with politicians. It is possible that if we had included measures of political self-efficacy better reflecting adolescents' actual civic behaviors (e.g., self-efficacy regarding voluntary work), the association between participation and the changes in self-efficacy beliefs could be found.

Finally, we found an effect of online, but not offline, participation on a greater acceptance of non-conventional, authority-challenging activism. Similarly, we found a weak effect of online participation on more negative attitudes towards social authorities and conventions, that is lower authoritarianism. The effect of offline participation on authoritarianism was exactly the opposite, but it should be noted that both effects on authoritarianism were not significant and thus should be treated only with caution. These findings outline a general trend in which online participation seems to rather enhance attitudes challenging systems and authorities, while offline participation decreases them. To take an optimistic perspective on the findings, we might interpret them by focusing on the beneficial effects of the online environment on youth development. Such an interpretation would emphasize that participating online can lead to the development of more independent and novel opinions through experiences with diverse online information resources (Kahne et al., 2012), online debates and argumentations, or active participation in the environment with less authority- or power-based barriers (Dahlgren, 2005, 2013; Dahlberg, 2007; Savigny, 2002). This could support positive views of online participation as a mean to enhance deliberation: to increase general awareness (Shah et al., 2005), develop more open yet critical perspectives on societal issues, and promote decreased compliance toward authorities, development of autonomy, and individuation (Fenton \& Barassi, 2011). However, we should not dismiss also a less optimistic interpretation. In our results, online participation did not predict changes in civic identity, which means that growing individuation is probably not accompanied by increasing social concern. Hence, a question remains as to whether the non-conventional and authority-challenging attitudes, developed through online participation, are oriented towards contributing to the common good (e.g., by challenging social injustice), or whether they might result, for instance, in greater acceptance of radically intolerant attitudes.

This study outlined the potential effect of online participation on youth civic development. Among the study's strengths are the large sample size and panel design. However, the study also has several limitations. The first limitation is the self-reported format of the data, which might be in future studies overcome by triangulation of 
more methods (e.g., by supplementing the survey data with interviews, or by consensual records of actual online behavior). Furthermore, we studied only three selected components related to civic development, yet there are other factors that can help our understanding of this process (e.g., the above-mentioned civic self-efficacy). Also, our conceptualization of online and offline civic participation captured only a limited range of activities, while others were not included. For instance, capturing a greater number of protest activities would help to deepen our insight into the examined developmental effects. Moreover, the answer scale for these activities was ordinal and did not distinguish more frequent participatory activities. Although the overall intensity of participation is partially captured via the overall involvement in the number of activities, the absence of the measurement of the more frequent participation poses a limitation and may be the reason why we did not detect some of the studied effects. Additionally, some non-significant effects might be caused by the fact that the link is not direct. We focused solely on the effect of participation; however, civic development is also affected by other factors, for example the social environment and the overall context (see e.g. Zaff, Malanchuk, \& Eccles, 2008), which, besides their own direct effect, can shape the effect of participation on civic development. Future studies are encouraged to include these factors to better understand youth civic development. Finally, since our data originate from the Czech Republic, our findings should be generalized to countries with similar political and democratic climate and rates of internet penetration.

Despite these limitations, our study contributes to the understanding of civic development in youth. Our findings support the presumption that the performed actions promote the development of certain characteristics connected to civic life. We also showed that the effect of online participatory activities is different from offline ones: they enhance the development of attitudes challenging social authorities but have no effect on the development of civic identity (which was increased via offline participation) and political self-efficacy (which was not linked with offline participation either). These findings highlight contributions and limits of online participation in adolescents' civic development, which should be reflected in further debates about the consequences of engagement in different types of participatory activities. Specifically, it should be recommended to encourage youth to engage in both forms of activities, since each form provides specific opportunities for the civic development; while engagement in online participatory activities solely is limited in this regard.

\section{Acknowledgements}

The authors acknowledge the support of the Czech Science Foundation (GA14-20582S), and the Faculty of Social Studies, Masaryk University.

\section{References}

Akdeniz, Y. (2002). Anonymity, democracy, and cyberspace. Social Research: An International Quarterly, 69, 223237.

Alwin, D. F., \& Krosnick, J. A. (1991). Aging, cohorts, and the stability of sociopolitical orientations over the life span. American Journal of Sociology, 97, 169-195. https://doi.org/10.1086/229744

Atkins, R., \& Hart, D. (2003). Neighborhoods, adults, and the development of civic identity in urban youth. Applied Developmental Science, 7, 156-164. https://doi.org/0.1207/S1532480XADS0703_6

Bakker, T. P., \& de Vreese, C. H. (2011). Good news for the future? Young people, Internet use, and political participation. Communication Research, 38, 451-470. https://doi.org/10.1177/0093650210381738

Bandura, A. (1997). Self-efficacy. New York: W. H. Freeman.

Bandura, A. (2006). Guide for constructing self-efficacy scales. In F. Pajares \& T. Urdan (Eds.), Self-efficacy beliefs of adolescents (pp. 307-337). Greenwich, CT: Information Age Publishing.

Bargh, J. A., \& McKenna, K. Y. (2004). The Internet and social life. Annual Review of Psychology, 55, 573-590.

https://doi.org/10.1146/annurev.psych.55.090902.141922 
Beaumont, E. (2010). Political agency and empowerment: Pathways for developing a sense of political efficacy in young adults. In L. R. Sherrod, J. Torney-Purta, \& C. A. Flanagan (Eds.), Handbook of research on civic engagement in youth (pp. 525-558). Hoboken: John Wiley \& Sons.

Beaumont, E. (2011). Promoting political agency, addressing political inequality: A multilevel model of internal political efficacy. The Journal of Politics, 73, 216-231. https://doi.org/10.1017/S0022381610000976

Bennett, W. L. (2008). Civic life online: Learning how digital media can engage youth. Cambridge, MA: The MIT Press. boyd, d. (2010). Social network sites as networked publics: Affordances, dynamics, and implications. In Z. Papacharissi (Ed.), Networked self: Identity, community, and culture on social network sites (pp. 39-58). New York, NY: Routledge.

Brundidge, J. (2010). Encountering "difference" in the contemporary public sphere: The contribution of the Internet to the heterogeneity of political discussion networks. Journal of Communication, 60, 680-700.

https://doi.org/10.1111/j.1460-2466.2010.01509.x

Buckingham, D. (Ed.). (2008). Youth, identity and digital media. Cambridge, MA: MIT Press.

Buckingham, D., \& Willett, R. (2006). Digital generations: Children, young people, and the new media. Mahwah, NJ: Lawrence Erlbaum Associates.

Caprara, G. V., Vecchione, M., Capanna, C., \& Mebane, M. (2009). Perceived political self-efficacy: Theory, assessment, and applications. European Journal of Social Psychology, 39, 1002-1020.

https://doi.org/10.1002/ejsp.604

Chen, Y., Conroy, N. J., \& Rubin, V. L. (2015). Misleading online content: Recognizing clickbait as "false news". In Proceedings of the 2015 ACM on Workshop on Multimodal Deception Detection (pp 15-19).

https://doi.org/10.1145/2823465.2823467

Český statistický úřad. (n. d.). Informační technologie v domácnostech a mezi jednotlivci [ICT in households and among individuals]. Český statistický úřad. Retrieved from https://www.czso.cz/csu/czso/domacnosti_a_jednotlivci

Cheung, G. W., \& Rensvold, R. B. (2002). Evaluating goodness-of-fit indexes for testing measurement invariance. Structural Equation Modeling, 9, 233-255.

https://doi.org/10.1207/S15328007SEM0902_5080/02671522.2014.908408

Christensen, H. S. (2011). Political activities on the Internet: Slacktivism or political participation by other means? First Monday, 16(2). https://doi.org/10.5210/fm.v16i2.3336

Cicognani, E., Zani, B., Fournier, B., Gavray, C., \& Born, M. (2012). Gender differences in youths' political engagement and participation. The role of parents and of adolescents' social and civic participation. Journal of Adolescence, 35, 561-576. https://doi.org/10.1016/j.adolescence.2011.10.002

Costello, M., Hawdon, J., Ratliff, T., \& Grantham, T. (2016). Who views online extremism? Individual attributes leading to exposure. Computers in Human Behavior, 63, 311-320. https://doi.org/10.1016/j.chb.2016.05.033

Dahlberg, L. (2007). The Internet, deliberative democracy, and power: Radicalizing the public sphere. International Journal of Media \& Cultural Politics, 3, 47-64. https://doi.org/10.1386/macp.3.1.47_1

Dahlgren, P. (2005). The Internet, public spheres, and political communication: Dispersion and deliberation. Political Communication, 22, 147-162. https://doi.org/10.1080/10584600590933160

Dahlgren, P. (2009). Media and political engagement: Citizens, communication and democracy. Cambridge, UK: Cambridge University Press.

Duckitt, J. (2009). Authoritarianism and dogmatism. In M. R. Leary \& R. H. Hoyle (Eds.), Handbook of Individual Differences in Social Behavior (pp. 298-317). New York, NY: Guilford Press.

Economist Intelligence Unit (2017). The Economist Intelligence Unit's Democracy Index. Retrieved from: https://infographics.economist.com/2017/Democracylndex/

Edwards, A. R. (2002). The moderator as an emerging democratic intermediary: The role of the moderator in Internet discussions about public issues. Information Polity, 7, 3-20. 
Ekström, M., \& Östman, J. (2013). Information, interaction, and creative production: The effects of three forms of Internet use on youth democratic engagement. Communication Research, 42, 796-818.

https://doi.org/10.1177/0093650213476295

Ekström, M., Olsson, T., \& Shehata, A. (2014). Spaces for public orientation? Longitudinal effects of Internet use in adolescence. Information, Communication \& Society, 17, 168-183. https://doi.org/10.1080/1369118X.2013.862288

Fenton, N., \& Barassi, V. (2011) Alternative media and social networking sites: The politics of individuation and political participation. The Communication Review, 14, 179-196. https://doi.org/10.1080/10714421.2011.597245

Finkel, S. E., Sigelman, L., \& Humphries, S. (1999). Democratic values and political tolerance. In J. P. Robinson, P. R. Shaver, \& L. S. Wrightsman (Eds.), Measures of political attitudes (pp. 203-296). San Diego: Academic Press.

Flanagan, C. A., Bowes, J. M., Jonsson, B., Csapo, B., \& Sheblanova, E. (1998). Ties that bind. Journal of Social Issues, 54, 457-475. https://doi.org/10.1111/j.1540-4560.1998.tb01230.x

Flanagan, C. A., Jonsson, B., Botcheva, L., Csapo, B., Bowes, J., Macek, P., Averina, I., \& Sheblanova, E. (1999). Adolescents and the 'Social Contract': Developmental roots of citizenship in seven countries. In M. Yates \& J. Youniss (Eds.), Roots of civic identity. Community service and civic engagement in youth: International perspectives (pp. 135-155). Cambridge: Cambridge University Press.

Freedom House (2017). Freedom in the World 2017.Czech Republic Profile. Retrieved from: https://freedomhouse.org/report/freedom-world/2017/czech-republic

Funke, F. (2005). The dimensionality of right-wing authoritarianism: Lessons from the dilemma between theory and measurement. Political Psychology, 26, 195-218. https://doi.org/10.1111/j.1467-9221.2005.00415.x

Garrett, R. K. (2009). Echo chambers online?: Politically motivated selective exposure among Internet news users. Journal of Computer-Mediated Communication, 14, 265-285. https://doi.org/10.1111/j.1083-6101.2009.01440.x

Gibson, R., \& Cantijoch, M. (2013). Conceptualizing and measuring participation in the age of the Internet: Is online political engagement really different to offline?. The Journal of Politics, 75, 701-716.

https://doi.org/10.1017/S0022381613000431

Hargittai, E. (2010). Digital Na(t)ives? Variation in internet skills and uses among members of the "net generation". Sociological Inquiry, 80, 92-113. https://doi.org/10.1111/j.1475-682x.2009.00317.x

Hirzalla, F., \& Van Zoonen, L. (2011). Beyond the online/offline divide how youth's online and offline civic activities converge. Social Science Computer Review, 29, 481-498. https://doi.org/10.1177/0894439310385538

Hooghe, M., \& Quintelier, E. (2014). Political participation in European countries: The effect of authoritarian rule, corruption, lack of good governance and economic downturn. Comparative European Politics, 12, 209-232. https://doi.org/10.1057/cep.2013.3

Chadwick, A., \& Howard, P. N. (Eds.) (2010). Routledge handbook of Internet politics. New York, NY: Routledge.

Jugert, P., Eckstein, K., Noack, P., Kuhn, A., \& Benbow, A. (2013). Offline and online civic engagement among adolescents and young adults from three ethnic groups. Journal of Youth and Adolescence, 42, 123-135.

https://doi.org/10.1007/s10964-012-9805-4

Kahne, J., Lee, N. J., \& Feezell, J. T. (2013). The civic and political significance of online participatory cultures among youth transitioning to adulthood. Journal of Information Technology \& Politics, 10, 1-20.

https://doi.org/10.1080/19331681.2012.701109

Kahne, J., Middaugh, E., Lee, N. J., \& Feezell, J. T. (2012). Youth online activity and exposure to diverse perspectives. New Media \& Society, 14, 492-512. https://doi.org/10.1177/1461444811420271

Kenski, K., \& Stroud, N. J. (2006). Connections between Internet use and political efficacy, knowledge, and participation. Journal of Broadcasting \& Electronic Media, 50, 173-192.

https://doi.org/10.1207/s15506878jobem5002_1

Kim, Y., Hsu, S. H., \& de Zúñiga, H. G. (2013). Influence of social media use on discussion network heterogeneity and civic engagement: The moderating role of personality traits. Journal of Communication, 63, 498-516.

https://doi.org/10.1111/jcom.12034 
Krosnick, J. A., \& Alwin, D. F. (1989). Aging and susceptibility to attitude change. Journal of Personality and Social Psychology, 57, 416-425. https://doi.org/10.1037/0022-3514.57.3.416

Lampe, C., Zube, P., Lee, J., Park, C. H., \& Johnston, E. (2014). Crowdsourcing civility: A natural experiment examining the effects of distributed moderation in online forums. Government Information Quarterly, 31, 317-326. https://doi.org/10.1016/j.giq.2013.11.005

Lenhart, A. (2015). Teens, social media \& technology overview 2015. Pew Research Center. Retrieved from: http://www.pewinternet.org/2015/04/09/teens-social-media-technology-2015/

Little, T. D., Cunningham, W. A., Shahar, G., \& Widaman, K. F. (2002). To parcel or not to parcel: Exploring the question, weighing the merits. Structural Equation Modeling: A Multidisciplinary Journal, 9, 151-173.

https://doi.org/10.1207/S15328007SEM0902_1

Livingstone, S., Couldry, N., \& Markham, T. (2007). Youthful steps towards civic participation: Does the internet help? In B. Loader (Ed.), Young citizens in the digital age: Political engagement, young people and new media (pp. 2134). London: Routledge.

Livingstone, S. (2009). Children and the Internet. Cambridge: Polity Press.

Lutz, C., Hoffmann, C. P., \& Meckel, M. (2014). Beyond just politics: A systematic literature review of online participation. First Monday, 19(7). https://dx.doi.org/10.5210/fm.v19i7.5260

Macková, A., \& Macek, J. (2015). Old and New media and Participation in Czech Society [Research Report]. Brno: Masarykova univerzita. Retrieved from:

https://is.muni.cz/repo/1306297/Old_and_New_Media_and_Participation_in_Czech_Society.pdf

Marsh, A., \& Kaase. M (1979). Measuring political action. In S. H. Barnes \& M. Kaase (Eds.), Political action: Mass participation in five Western democracies (pp. 57-96). Beverly Hills: Sage.

Metz, E., McLellan, J., \& Youniss, J. (2003). Types of voluntary service and adolescents' civic development. Journal of Adolescent Research, 18, 188-203. https://doi.org/10.1177/0743558402250350

Min, S.-J. (2010). From the digital divide to the democratic divide: Internet skills, political interest, and the secondlevel digital divide in political internet use. Journal of Information Technology \& Politics, 7, 22-35.

https://doi.org/10.1080/19331680903109402

Morozov, E. (2011). The net delusion. New York, NY: PublicAffairs.

Mossberger, K., Tolbert, C. J., \& McNeal, R. S. (2007). Digital citizenship: The Internet, society, and participation. Cambridge: MIT Press.

Nagy, P., \& Neff, G. (2015). Imagined affordance: Reconstructing a keyword for communication theory. Social Media + Society, 1(2). https://doi.org/10.1177/2056305115603385

Oser, J., Hooghe, M., \& Marien, S. (2013). Is online participation distinct from offline participation? A latent class analysis of participation types and their stratification. Political Research Quarterly, 66, 91-101.

https://doi.org/10.1177/1065912912436695

Östman, J. (2012). Information, expression, participation: How involvement in user-generated content relates to democratic engagement among young people. New Media \& Society, 14, 1004-1021.

https://doi.org/10.1177/1461444812438212

Pajares, F., \& Urdan, T. C. (Eds.). (2006). Self-efficacy beliefs of adolescents. Greenwich, CT: IAP.

Park, H. M. \& Perry, J. L. (2008). Do campaign Web sites really matter in electoral civic engagement? Empirical evidence from the 2004 post-election Internet tracking survey. Social Science Computer Review, 26, pp. 190-212. https://doi.org/10.1177/0894439307309026

Pauwels, L., \& Schils, N. (2016). Differential online exposure to extremist content and political violence: Testing the relative strength of social learning and competing perspectives. Terrorism and Political Violence, 28, 1-29.

https://doi.org/10.1080/09546553.2013.876414 
Quintelier, E., \& Vissers, S. (2008). The effect of Internet use on political participation an analysis of survey results for 16-year-olds in Belgium. Social Science Computer Review, 26, 411-427.

https://doi.org/10.1177/0894439307312631

Quintelier, E., \& Van Deth, J. W. (2014). Supporting democracy: Political participation and political attitudes. Exploring causality using panel data. Political Studies, 62(S1), 153-171.

Savigny, H. (2002). Public opinion, political communication and the internet. Politics, 22, 1-8. https://doi.org/10.1111/1467-9256.00152

Sears, D. O. \& Brown, C. (2013). Childhood and adult political development. In L. Huddy, D. O. Sears, J. S. Levi (Eds.), The Oxford handbook of political psychology ( $2^{\text {nd }}$ ed.)(pp. 59-95). Oxford University Press: New York.

Šerek, J., \& Machackova, H. (2014). Online only: Which Czech young adults prefer online civic participation?. Cyberpsychology: Journal of Psychosocial Research on Cyberspace, 8(3), article 6. https://doi.org/10.5817/cp2014-3-6

Shah, D. V., Cho, J., Eveland, W. P., \& Kwak, N. (2005). Information and expression in a digital age modeling Internet effects on civic participation. Communication Research, 32, 531-565.

https://doi.org/10.1177/0093650205279209

Sherrod, L., Torney-Purta, J., \& Flanagan, C. (Eds.). (2010). Handbook of research on civic engagement in youth. Hoboken, N.J: Wiley \& Sons.

Smith, A. W., Schlozman, K. L., Verba, S., \& Brady, H. (2009). The Internet and civic engagement. Washington, DC: Pew Internet \& American Life Project. Retrieved from: http://www.pewinternet.org/files/oldmedia/Files/Reports/2009/The\%2520Internet\%2520and\%2520Civic\%2520Engagement.pdf

Sohl, S., \& Arensmeier, C. (2015). The school's role in youths' political efficacy: Can school provide a compensatory boost to students' political efficacy? Research Papers in Education, 30, 133-163. https://doi.org/10.1080/02671522.2014.908408

Štětka, V., \& Mazák (2014). Whither slacktivism? Political engagement and social media use in the 2013 Czech Parliamentary elections. Cyberpsychology: Journal of Psychosocial Research on Cyberspace, 8(3), article 7. https://doi.org/10.5817/CP2014-3-7

Subrahmanyam, K., \& Smahel, D. (2011). Digital youth: The role of media in development. New York, NY: Springer.

Suler, J. (2004). The online disinhibition effect. CyberPsychology \& Behavior, 7, 321-326.

https://doi.org/10.1089/1094931041291295

Tandoc, E. C., Ling, R., Westlund, O., Duffy, A., Goh, D., \& Wei, L. Z. (2017). Audiences' acts of authentication in the age of fake news: A conceptual framework. New Media \& Society. Advanced online publication.

https://doi.org/10.1177/1461444817731756

Ťápal, A. (2012). Kognitivně-motivační dispozice autoritářství [Cognitive-motivational dispositions of authoritarianism] (Unpublished diploma thesis). Brno: Masaryk University. Retrieved from https://is.muni.cz/th/357607/fss_b?lang =en

Tsitsika, A. K., Tzavela, E. C., Janikian, M., Ólafsson, K., lordache, A., Schoenmakers, T. M., . . \& Richardson, C. (2014). Online social networking in adolescence: Patterns of use in six European countries and links with psychosocial functioning. Journal of Adolescent Health, 55, 141-147.

https://doi.org/10.1016/j.jadohealth.2013.11.010

Valenzuela, S. (2013). Unpacking the use of social media for protest behavior the roles of information, opinion expression, and activism. American Behavioral Scientist, 57, 920-942. https://doi.org/10.1177/0002764213479375

Valkenburg, P. M., Peter, J., \& Walther, J. B. (2016). Media effects: Theory and research. Annual Review of Psychology, 67, 315-338. https://doi.org/10.1146/annurev-psych-122414-033608

Verba, S., Schlozman, K. L., \& Brady, H. E. (1995). Voice and equality: Civic voluntarism in American politics. Cambridge: Harvard University Press.

Vissers, S., \& Stolle, D. (2014). The Internet and new modes of political participation: Online versus offline participation. Information, Communication \& Society, 17, 937-955. https://doi.org/10.1080/1369118X.2013.867356 
Warren, A. M., Sulaiman, A., \& Jaafar, N. I. (2014). Facebook: The enabler of online civic engagement for activists. Computers in Human Behavior, 32, 284-289. https://doi.org/10.1016/j.chb.2013.12.017

Wojcieszak, M. E., \& Mutz, D. C. (2009). Online groups and political discourse: Do online discussion spaces facilitate exposure to political disagreement? Journal of Communication, 59, 40-56.

https://doi.org/10.1111/j.1460-2466.2008.01403.x

Wright, S., \& Street, J. (2007). Democracy, deliberation and design: the case of online discussion forums. New Media \& Society, 9, 849-869. https://doi.org/10.1177/1461444807081230

Xenos, M., Vromen, A., \& Loader, B. D. (2014). The great equalizer? Patterns of social media use and youth political engagement in three advanced democracies. Information, Communication \& Society, 17, 151-167. https://doi.org/10.1080/1369118X.2013.871318

Yates, M., \& Youniss, J. (1998). Community service and political identity development in adolescence. Journal of Social Issues, 54, 495-512. https://doi.org/10.1111/j.1540-4560.1998.tb01232.x

Youniss, J., McLellan, J. A., \& Yates, M. (1997). What we know about engendering civic identity. American Behavioral Scientist, 40, 620-631. https://doi.org/10.1177/0002764297040005008

Zaff, J. F., Malanchuk, O., \& Eccles, J. S. (2008). Predicting positive citizenship from adolescence to young adulthood: The effects of a civic context. Applied Development Science, 12, 38-53.

https://doi.org/10.1080/10888690801910567

\section{Correspondence to:}

Hana Machackova

Institute for Research on Children, Youth. and Family

Faculty of Social Studies

Masaryk University

Jostova 10

60200 Brno

Czech Republic

E-mail: hmachack(at)fss.muni.cz

Editorial record: First submission received on December 6, 2016. Revisions received on November 27, 2017, and December 26, 2017. Accepted for publication on December 28, 2017.

\section{About Authors}

Hana Machackova, Ph.D. is a postdoctoral researcher at Masaryk University, where she works at the Institute for Research of Children, Youth, and Family. She is a member of Interdisciplinary Research Team on Internet and Society (IRTIS), which researches social-psychological implications of the internet and technology. Her research interests include cyberbullying and online aggression, online communities, online participation, or self-disclosure and privacy on the internet.

Jan Šerek, Ph.D. is a postdoctoral researcher at the Faculty of Social Studies, Masaryk University. He received his Ph.D. in Social Psychology. His research interest involves political and civic socialization of young people and psychological aspects of democracy. 